\title{
RELATIONSHIP BETWEEN BODY MASS AND BODY LENGTH IN CAPYBARAS (HYDROCHOERUS HYDROCHAERIS)
}

\author{
Katia Maria Paschoaletto Micchi de Barros Ferraz, Kelly Bonach, Luciano Martins Verdade
}

Biota Neotropica v5(n1) - http://www.biotaneotropica.org.br/v5n1/pt/abstract?short-communication+BN03405012005

Recebido em 10/12/2004

Revisado em 10/20/2005

Publicado 14/03/2005

\author{
Laboratório de Ecologia Animal, ESALQ, Universidade de São Paulo \\ Cx. P. 09, Piracicaba, SP, 13418-900 BRASIL \\ Email:kferraz@esalq.usp.br
}

\begin{abstract}
As a part of a management program we captured 39 capybaras (Hydrochoerus hydrochaeris) in an agroecosystem at the east central region of the State of São Paulo, Brazil from March 2001 to May 2002. Average adult male body mass was 54.1 $\pm 8.05 \mathrm{~kg}$, and average adult female body mass was $62.0 \pm 12.03 \mathrm{~kg}$. Average juvenile male body mass was $23.0 \pm 8.28 \mathrm{~kg}$, and average juvenile female body mass was $26.7 \pm 5.86 \mathrm{~kg}$. Males and females presented a significant variation in the allometric relation between body mass and body length. Body mass and body length had a high correlation for both adult males and adult females. These results from capybaras in agroecosystem might be relevant for further management programs.
\end{abstract}

Key words: Capybaras, body mass, body length, agroecosystem

\section{Resumo}

Trinta e nove capivaras (Hydrochoerus hydrochaeris) foram capturadas como parte de um programa de manejo em um agroecossistema na região centro-oeste do estado de São Paulo, de março de 2001 a maio de 2002. A massa corpórea média de machos adultos foi de $54.1 \pm 8.05 \mathrm{~kg}$, enquanto que de fêmeas adultas foi de $62.0 \pm 12.03 \mathrm{~kg}$. A massa corpórea média de machos jovens foi de $23.0 \pm 8.28 \mathrm{~kg}$, enquanto que de fêmeas jovens foi de $26.7 \pm 5.86 \mathrm{~kg}$. Machos e fêmeas apresentaram variação significativa na relação alométrica entre massa e comprimento corpóreos. Massa e comprimento corpóreos apresentaram alta correlação entre machos e fêmeas adultas. Estes resultados de capivaras em agroecossistemas podem ser importantes para futuros programas de manejo.

Palavras-chave: capivara, massa corpórea, comprimento corpóreo, agroecossistemas 


\section{Introduction}

Capybaras, the largest living rodent in the world, have been considered as a potential plague in the east central region of the State of São Paulo, especially in the Piracicaba river basin, a well developed and anthropogenic region in the State. Apparently, the process of habitat deforestation has been favoring capybaras population increase in this region, mainly due to the great food availability by agriculture such as corn, sugar cane, and rice (Ferraz et al., 2003). Besides the natural vegetation (grass and aquatic plants - Ojasti, 1973), capybaras consume mainly $\mathrm{C} 4$ domestic plants what has been probably contributing for the species adaptation to anthropogenic habitats. In this region, capybara habitats can be described as agricultural fields in flat areas near watercourses (Ferraz 2004). Capybara has also been reported to cause damage in agricultural fields at the University Campus (Ferraz et al., 2003) and its relationship with the occurrence of ricketsiosis has also been studied (Labruna et al., 2004). As part of a management program, capybaras have been monitored in this study sites weekly by direct counts since July 1998 (Verdade $\&$ Ferraz 2005). In this study we present some body mass and body length from 39 capybaras captured in these anthropogenic habitats.

\section{Material and Methods}

The site where capybaras were captured could be described as an agroecosystem located at Campus "Luiz de Queiroz", from the University of São Paulo, in Piracicaba, Brazil (22\%41'51.2" S and 47³3'40.0" W, in average 546 $\mathrm{m}$ above see level) (Figure 1). The ecosystem was composed by a mixed field of agriculture (mainly corn, approximately $90 \mathrm{ha}$ ), a fragment of second-growth semi-deciduous native forest ( $7 \mathrm{ha}$ ), a stand of mixed implanted forest (Pinus spp and Eucalyptus spp, 2.7 ha), a small field of exotic pasture (mostly Brachiaria decumbens, approximately $1 \mathrm{ha}$ ), and an artificial reservoir (1.7 ha).

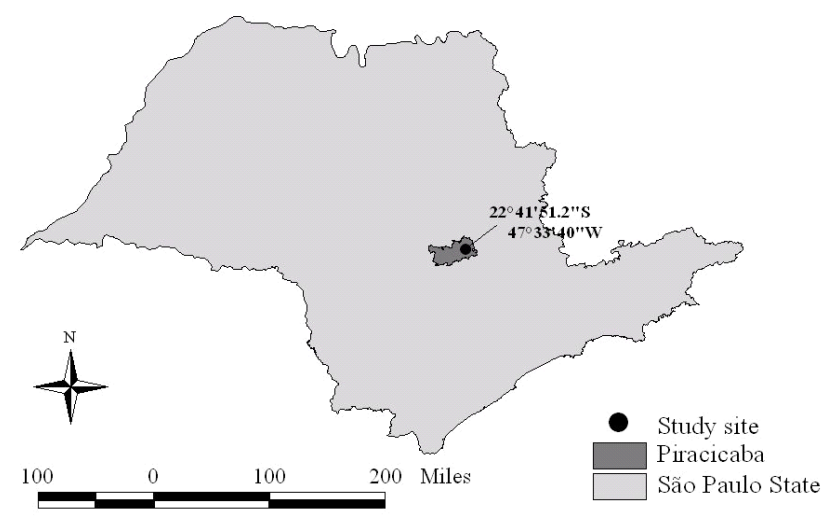

Figure 1 - Location of the study area, Piracicaba, São Paulo, Brazil.
As part of a management program we captured 39 capybaras (Hydrochoerus hydrochaeris) in this agroecosystem from March 2001 to May 2002 (n=10 in March 2001; $n=28$ in October 2001; and $n=1$ in May 2002) in two small-fenced area. Based on the species monitoring data, we believe that all captured individuals belonged to the same group.

\section{Results and Discussion}

Fifteen adults (nine males and six females), 19 juveniles (five males and fourteen females), and five young (two males and three females) were captured in the study area. Average adult male body mass was $54.1 \pm 8.05 \mathrm{~kg}$ (44.0-68.0) and average adult female body mass was $62.0 \pm 12.03 \mathrm{~kg}$ (48.0-81.0). Average juvenile male body mass was $23.0 \pm$ $8.28 \mathrm{~kg}(15.0-37.0)$ and average juvenile female body mass was $26.7 \pm 5.86 \mathrm{~kg}(15.0-34.0)$ (Table 1). The average body mass of adults and juveniles males and females from the present study was bigger than those from other studies (Ojasti 1973, Cordero \& Ojasti 1981, Schaller 1983, Herrera 1986, Mones \& Ojasti 1986, Herrera 1992), except from Alho et al. (1989) (Table 2). The present results suggest that in agroecosystems capybaras can reach bigger body mass than in natural habitats possibly because of food availability (Ferraz et al. 2003).

Body mass can be an important attribute to define social position in the dominance hierarchy of capybara grouping. According to Moreira et al. (1997), body mass was significantly correlated to the volume of the snout and anal gland, presence to the coated hairs in the anal glands and testes mass, suggesting that dominance in capybaras is more associated with androgen-dependent scent glands than with sperm production. Mones \& Ojasti (1986) suggest that capybaras evince a latitudinal cline with body size and mass increasing as latitude increases.

The heaviest individual found at the present study was an $81.0 \mathrm{~kg}$ non-pregnant female, close to the record described by Mones (1973) of a $91 \mathrm{~kg}$ female also found in São Paulo, Brazil, but above the heaviest female $(65.5 \mathrm{~kg})$ recorded by Ojasti (1973) in Venezuela. At this study most females were non-pregnant contrary to the pattern found by Ojasti (1973). These different patterns could be possibly explained by the seasons when captures were made in both studies. In São Paulo, there seems to be a peak at the reproductive activity in November (Verdade \& Ferraz, 2005). Cordero \& Ojasti (1981) assumed that a population of capybaras in a forested habitat presented older and therefore heavier individuals than another population from Savannah habitat.

In this study, males and females presented similar body mass $(\mathrm{t}=0.90$, d.f. $=32, \mathrm{P}=0.37$ for the whole sample, $\mathrm{t}=1.54$, d.f. $=13, \mathrm{P}=0.14$ for the adults, and $\mathrm{t}=1.09$, d.f. $=17$, $\mathrm{P}=0.29$ for the juveniles). 


\begin{tabular}{lcccc}
\hline & Body mass (kg) & Min. & Max. & $\mathrm{n}$ \\
\hline Males (adults and juveniles) & $42.96 \pm 17.30$ & 15.0 & 68.0 & 14 \\
Females (adults and juveniles) & $41.73 \pm 17.36$ & 15.0 & 81.0 & 20 \\
Adults (males and females) & $57.23 \pm 10.24$ & 44.0 & 81.0 & 15 \\
Juveniles (males and females) & $25.74 \pm 6.54$ & 15.0 & 37.0 & 19 \\
Adult males & $54.06 \pm 8.05$ & 44.0 & 68.0 & 9 \\
Adult females & $62.00 \pm 12.03$ & 48.0 & 81.0 & 6 \\
Juvenile males & $23.00 \pm 8.28$ & 15.0 & 37.0 & 5 \\
Juvenile females & $26.71 \pm 5.86$ & 15.0 & 34.0 & 14
\end{tabular}

TABLE 2. Body mass (kg) of capybaras.

\begin{tabular}{|c|c|c|c|c|c|}
\hline \multirow{3}{*}{ Localities } & \multicolumn{4}{|c|}{ Average body mass (kg) } & \multirow{3}{*}{ References } \\
\hline & Adult & Adult & Juvenile & Juvenile & \\
\hline & male & female & male & female & \\
\hline \multicolumn{6}{|l|}{ São Paulo, Brazil } \\
\hline & 54.1 & 62.0 & 23.0 & 26.7 & Present study \\
\hline \multirow[t]{2}{*}{ Pantanal, Brazil } & 41.8 & 36.8 & - & - & Schaller (1983) \\
\hline & 57.57 & 51.19 & 14.08 & 15.55 & Alho et al. (1989) \\
\hline \multirow[t]{3}{*}{ Llanos, Venezuela } & 48.63 & 49.80 & - & - & Ojasti (1973) \\
\hline & $38.4-42.4$ & $37.9-39.9$ & - & - & Herrera (1986) \\
\hline & 43.1 & 42.2 & 13.9 & 14.3 & Herrera (1992) \\
\hline
\end{tabular}


Likewise, males and females presented similar body length (from the top of the nose to the end of the tail) $(\mathrm{t}=$ 0.89 , d.f. $=23, \mathrm{P}=0.38$ for the whole sample, $\mathrm{t}=-0.07$, d.f. $=$ $17, \mathrm{P}=0.94$ for the adults, and $\mathrm{t}=-1.46$, d.f. $=12, \mathrm{P}=0.17$ for the juveniles). However, males and females presented a significant variation (ANCOVA: $\mathrm{F}=5.05$, d.f. $=24, \mathrm{P}=0.035$ ) in the allometric relation between body mass and body length. Therefore, we can infer that males and females present similar body size, but different body shape, what means that capybaras present some sexual dimorphism at least in adults. Herrera (1986) noticed a slight sexual dimorphism in adults in the relationship between their body mass and length of hind foot.

Body mass and body length had a high correlation for both adult males and adult females ( $22=0.98$ and $\mathrm{R} 2=$ 0.94 , respectively). The relationship between body mass $(\mathrm{kg})$ and body length $(\mathrm{cm})$ for adult can be described by the following regression models: $\mathrm{BMm}=-73.8256+1.03223 \mathrm{Lm}$ $(\mathrm{R} 2=97.9 \%)$, and $\mathrm{BMf}=-81.1077+1.07097 \mathrm{Lf}(\mathrm{R} 2=94.0 \%)$, where $\mathrm{BMm}=$ male body mass $(\mathrm{kg}), \mathrm{BMf}=$ female body mass $(\mathrm{kg}), \mathrm{Lm}=$ male length $(\mathrm{cm})$, and $\mathrm{Lf}=$ female length $(\mathrm{cm})$. Although the results presented here are related to a small sample size, they are the first records from capybaras of an anthropogenic habitat. These results might be relevant for further management programs.

\section{Acknowledgments}

The present study has been partially supported by Fundação de Amparo à Pesquisa do Estado de São Paulo FAPESP (Procs. Nos. 00/00180-9, 00/00602-0, and 00/005820 ) and Prefeitura do Campus "Luiz de Queiroz" / USP. Gustavo R. M. Pinto, Marli Penteado and Paulo Bezerra participated in the fieldwork.

\section{Literature Cited}

ALHO, C.J.R., CAMPOS, Z.M. \& GONÇALVES, H.C. 1989. Ecology, social behavior and management of the capybara in the Pantanal of Brazil. In. Advances in Neotropical Mammalogy (Redford, K.H. \& Eisenberg, J.F., eds.). Sandhill Crane, Gainesville, FL. p.163-194.

CORDERO R., G.A., OJASTI, J. 1981. Comparison of capybara populations of open and forested habitats. J.Wildlife Manage 45(1): 267-271.

FERRAZ, K.M.P.B. 2004. Distribuição espacial da capivara (Hydrochoerus hydrochaeris) em função da paisagem na bacia do rio Piracicaba, SP. Tese (doutorado). Escola Superior d Agricultura “Luiz de Queiroz", Universidade de São Paulo. 115p.

FERRAZ, K.M.P.M.B., LECHEVALIER, M., COUTO, H.T.Z. \& VERDADE, L.M. 2003. Damage caused by capybaras in a corn field, São Paulo, Brasil. Scientia Agricola 60(1): 191-194.
HERRERA, E.A. 1986. The behavioural ecology of capybara, Hydrochoerus hydrochaeris. Ph.D. Thesis, University of Oxford, Oxford, U.K.

HERRERA, E.A. 1992. Growth and dispersal of capybaras (Hydrochaerus hydrochaeris) in the Llanos of Venezuela. J. Zool. London 228: 307-316.

LABRUNA, M.B., WHITWORTH, T., HORTA, M.C., BOUYER, D.H., MCBRIDE, J.W., PITER, A., POPOV, V., GENNARI, S.M. \& WALKER, D.H. 2004. Rickettsia species infecting Amblyomma cooperi ticks from an area in the state of São Paulo, Brazil, where Brazilian Spotted Fewer is endemic. J Clin Microbiology 42(1): 90-98.

MONES, A. 1973. Estudios sobre la familia Hydrochoeridae (Rodentia), I. Introducción e historia taxonômica. Rev. Bras. Biol 33:277-283.

MONES, A., OJASTI, J. 1986. Hydrochoerus hydrochaeris. Mamm Species 264: 1-7.

MOREIRA, J.R., MACDONALD, D.W.\& CLARKE, J.R. 1997. Correlates of testis mass in capybaras (Hydrochaeris hydrochaeris): dominance assurance or sperm production. J. Zool. London 241: 457-463.

OJASTI, J. 1973. Estudio Biológico del Chigüire o Capibara. Fondo Nacional de Investigaciones Agropecuarias, Caracas, Venezuela.

SCHALLER, G.S. 1983. Mammals and their biomass on a Brazilian ranch. Arquiv Zool 31(1):1-36.

VERDADE, L.M. \& FERRAZ, K.M.P.M.B. In press. Capybaras on an anthropogenic habitat in Southeastern Brazil. Brazilian Journal of Biology 66(2) (in press)

Title: Relationship between body mass and body length in Capybaras (Hydrochoerus hydrochaeris).

Authors: Katia Maria Paschoaletto Micchi De Barros Ferraz, Kelly Bonach, Luciano Martins Verdade

Biota Neotropica, Vol. 5 ( number 1): 2005

http://www.biotaneotropica.org.br/v5n1/pt/ abstract?short-communication+BN03405012005

Recebido em 10/12/2004

Revisado em 10/20/2005

Publicado 14/03/2005

ISSN 1676-0611 